\title{
The Curriculum Adaptation Model in Fulfilling the Learning Need for Diverse Students at Inclusive Classroom
}

\author{
Dinar Westri Andini ${ }^{1, *}$, Ayu Rahayu ${ }^{1}$, C. Asri Budiningsih ${ }^{2}$, Mumpuniarti $^{3}$ \\ ${ }^{1}$ PGSD Department, Faculty of KIP, Universitas Sarjanawiyata Tamansiswa, Indonesia \\ ${ }^{2}$ TP Department, Faculty of KIP, Universitas Negeri Yogyakarta, Indonesia \\ ${ }^{3}$ PLB Department, Faculty of KIP, Universitas Negeri Yogyakarta, Indonesia
}

Received December 9, 2019; Revised December 30, 2019; Accepted February 25, 2020

Copyright $\odot 2020$ by authors, all rights reserved. Authors agree that this article remains permanently open access under the terms of the Creative Commons Attribution License 4.0 International License

\begin{abstract}
Inclusive education is one of the efforts to provide equal rights for all students in getting an equal education. One of the internal factors that support the success of inclusive education is the teacher. The teacher is expected to design a learning model that can accommodate the diversity of their students in the class. However, in reality, the learning process in class still impersonates, and there is no struggle to divide the characteristics of each student. Even, the students who have different abilities and special needs are just served the same learning material without considering their skills. Therefore, the efforts are needed for developing curriculum adaptation models that can meet the learning needs of all students' diversity in terms of learning readiness, learning styles and interests. This method used in this research is the R\&D method by analyzing the needs and exploring the classroom teachers ability in 25 elementary schools at Special Region of Yogyakarta, especially in preparing learning activities in the classroom, internal school perceptions about diversity and educational services for all. Then, it is expected that the results of the data obtained can produce curriculum adaptation models and it can be suitable for 10 elementary schools at Special Region of Yogyakarta.
\end{abstract}

Keywords Curriculum Adaptation, Diversity, Inclusive Education

\section{Introduction}

Proper education is right for all students. The education does not differentiate the specific racial, ethnic backgrounds, religions, abilities, characteristics or diversity. It means that education must be equal for all students. Student as unique individuals has different characteristics, they have different learning models so that the education must provide equal opportunities based on their skills to all students in reaching their potential and adapt to their environment [1]. This inclusive learning model will trigger the tolerance, respect, cooperative and coexist because this inclusive model is also seen as the participation of all students in the school and classroom as their learning Community [2].

Indonesia motto, namely "Bhinneka Tunggal Ika" proves that Indonesia accepts the existence of diversity. The 1945 Constitution also states that every citizen has the right to receive education, and the government has to provide the educational facilities and infrastructure that support the education process sustainability. Article 31 paragraph (1) stated that every citizen has the right to get education and Article 2 state that every citizen is required to join basic education, and the government is obliged to provide the fund. Within the inclusive education context, they arranged the true meaning of inclusive education namely the equality for accessing the education, including various human capabilities and abilities such as language, age, culture, gender, and diversity [3]. Innovative, inclusive education is an educational innovation that repels anti-discrimination attitudes, the struggle of equality and the equal opportunities, justice, the extension of access to the education for all people and the improvement the education quality and an effort to change people's attitudes towards disability.

The good education quality requires various supports from all parties, both from internal and external of the school parties. The successive of this inclusive education will help to complete basic education and provide an opportunity for all students to get the proper education. 
It is expected that each school also develops and enhances the implementation of inclusive education in their respective schools in purpose to make good education quality for all students. However, the teachers in private and public schools feel that the implementation of inclusive education which respects the diversity especially in both levels namely, the skill/readiness in learning, interests and student learning styles is still impracticable. The teacher still feels insecure, afraid, lacked and unsure in creating an inclusive environment [4] so that the implementation of this learning model in the classroom in considering students' diversity is still not achieved. The student is still only coming and receiving the material without considering the suitability with their skills. Some teachers in classrooms still use one-way and monotonous methods to teach their students so that some students feel bored, not focusing on the learning process and the teachers face the difficulty in making the assessments for disability [5]. Indeed, some teachers feel burdened when teaching the student who has differences in academic skills or the student who has certain characteristics. Diverse student skills are still not accommodated. This statement implies that student who has lower abilities than the other students is still forced on a predetermined curriculum and in the classroom student who has lower understanding of the material is only coming to the class. The learning method also still looks monotonous and passive.

The results of the study entitled "The Implementation of Different Instruction Models in Accommodating Student Diversity and Its Impact to Inclusiveness, Participation, Learning Motivation and Students' Understanding Levels in Inclusive Classes" prove that the student diversity in the classroom is good in terms of differences in abilities, interests and learning styles of students who can be mutually actively participating in the learning process [6]. The final results of this study indicate an increase in the previous low level of inclusiveness, namely at 21.4 points to the 48 ideal scores, finally become 45.48. Similarly, participation, motivation to learn and also the level of understanding of students in inclusive classes have increased. Therefore, it can be concluded that by applying the differentiated instruction model, the implementation of the learning process in the classroom becomes effective by showing good participation and collaboration between students as a pilot project of inclusive classrooms. There is an increase in understanding and motivation for students learning in class.

The implementation of differentiated instruction models considers the learning readiness of each individual, learning styles and interests. At the initial of the semester the teacher must conduct a pre-assessment by revealing the characteristics of each student in the class, so that the learning process to be carried out is more effective because the teacher will connect learning with how students receive the information related to their learning interest and the students' learning readiness in class [7]. Inside the concept of inclusive education, teachers must also remove obstacles that are faced by the student. The teachers must strive to meet students' different learning readiness, so learning outcomes must also be adjusted to the level of students' learning readiness. It is required the combination of each part in the differentiated instruction model with the determination of different achievement standards. However, all children with different abilities must learn together in the same environment with their peers. The curriculum adaptation is needed by making modifications, namely determining the suitability of learning achievement standards and / or accommodation looking for alternative learning [8] which is expected to be able to eliminate certain barriers so that all children can reach achievement and actively participate in learning [9].

Based on the background above, an effort is required to develop curriculum adaptation models that aims to realize non-physical accessibility, especially in learning in inclusive classes and it can help teachers meet the diverse needs of students both in terms of their ability/readiness to learn, their interests and their learning styles which implemented in class. Indeed, this innovative method will be very supportive with government programs in the successive in implementing the equal education for all / inclusive and also help teachers in fulfilling the needs and the various abilities of students in the class so that it can create a friendly education.

\subsection{Literature Review}

Inclusive education is education based on an open spirit to embrace all groups in education (Education for All). Inclusive Education is an educational implementation that has a multicultural view that can help students to understand, accept, and respect other people in different ethnicities, cultures, values, personalities, and physical and psychological functioning.

Ainscow developed the dimensions of inclusive practice into 16 indicators contained in the inclusion index, namely: a) The teacher makes learning plans (class activities are planned based on the situation of students), b) this learning model supports all students to participate actively in class, c) this learning model develops an understanding of the students diversity including disability, d) Students are actively involved in learning process including disability, e) All students collaborate with each other f) Conduct an assessment to control the achievement progress, g) Class discipline is the basis of mutual respect, $h$ ) Teachers learning plan, teach it and review with partners, including making IEP planning for disability, i) Special partners or teachers provide support in learning in class and collaborating with each other and active participate. j) The teacher gives homework to support students' learning activities, k) All students get 
the opportunity to learn outside the classroom, 1) Students' diversities are used as strengths in the learning and teaching process, $\mathrm{m}$ ) Staff (human resources) experts are used in full score, n) Teachers develop the use of available resources together to support activities and actively participate in collaborating programs, ranging from assessment, program preparation to assessing and reporting, o) The differences between students are used as sources to support activities in learning and participating, p) Learning resources are given fairly (e.g. aware of the potential for Disability) or expert resources available at school are fully utilized [2].

The curriculum used in inclusive schools is adapting the curriculum, where this curriculum is designed according to the needs of students. This curriculum contains lessons and skills by the students' level of ability in providing the learning materials that are appropriate with the abilities and students' needs [10].

The teacher can plan to design and adapt the curriculum based on the results of the assessment of the child's level of ability/readiness to learn, the learning interest of the student, the learning styles and knowledge that the child has previously obtained (Prior Knowledge), so that each student will get various achievement standards based on their abilities. This learning model is fundamental to be done by the teacher, because in this way, the teacher can find out the students' level of ability. The level of learning ability (Learning Level) of each child divided into three, among others: a) Independent Level, b) Instructional Level, and c) Frustration Level [11].

The adaptation of the curriculum can be by changing the contents of the curriculum/target that must be achieved and selecting appropriate learning strategies according to the level of understanding, interest and learning styles of students (modification) or from the results of the assessment which is done, the teacher gets the conclusion that the child is actually able to reach the standard/target which has only been set as a method, learning strategies need to be distinguished from another student's accommodation [8].

The classes characterized by various cultural and linguistic require various strategies to differentiate teaching plan so that the various and a lot of students' needs are met. In differentiated classes, the teacher will start teaching based on needs, readiness (where the student is), interests and then use many teaching models and instructional arrangements to ensure that students achieve their achievements. [12]

All students are able to learn, but they have different abilities and learning capabilities in the classroom. A teacher must be careful and aware of the various ability of each student before giving instruction. The detailed phases in developing differentiated learning are as follows:

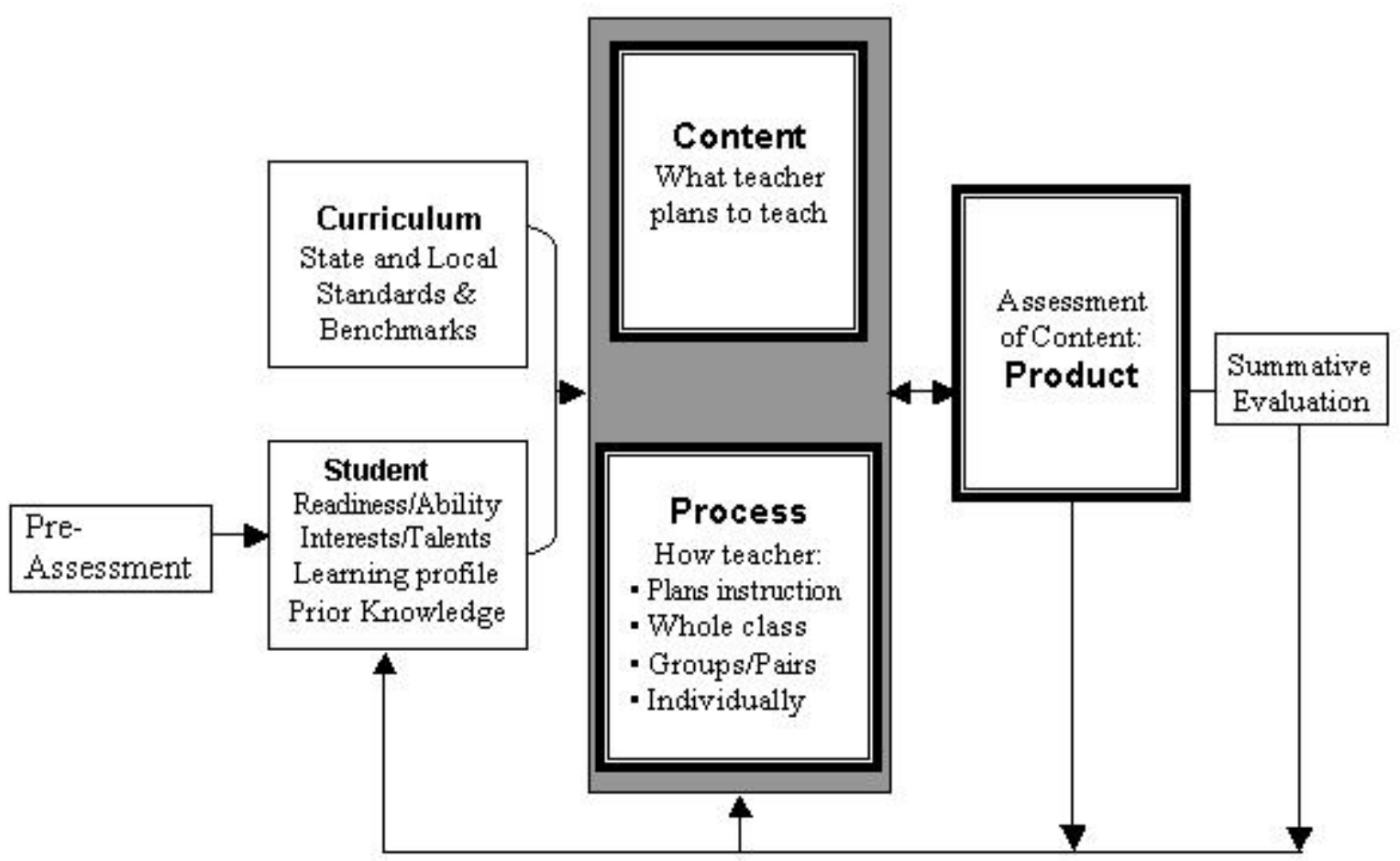

(adaoted from Oakford, L. \& Jones, L., 2001)

Source: Oaksford, L. \& Jones, L., 2001

Figure 1. The Picture of Implementing Procedures the "Differentiated Instruction Model" 


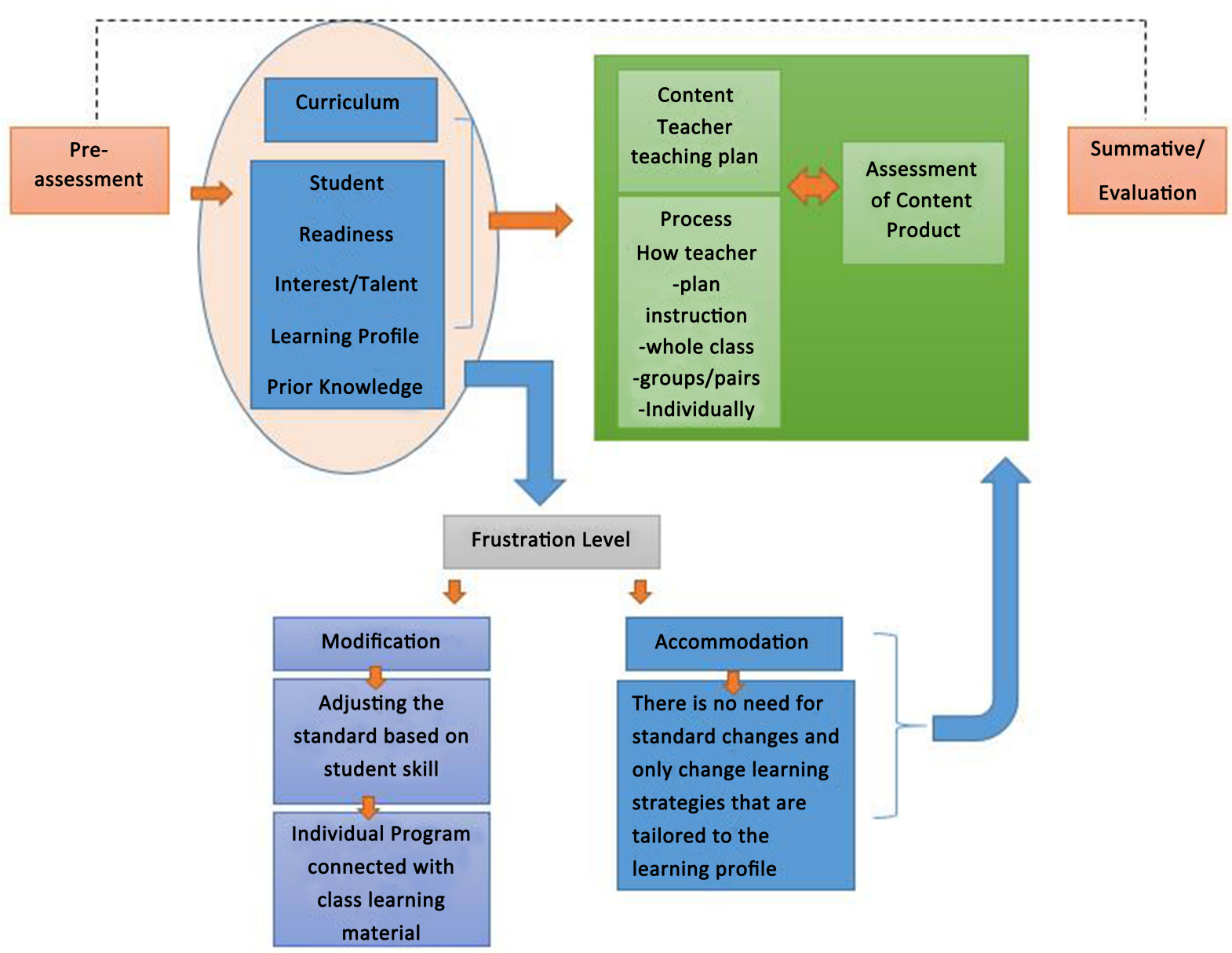

Figure 2. Flowchart intern planning accommodating student diversity

In 2014, the researchers conducted classroom action research by applying differentiated instruction learning in accommodating students' diversity and its impact on inclusiveness, participation, motivation to learn and the level of the student in understanding the material in inclusive classes. The results of the development model by combining the theories of Le Ann Jung \&Guskey (2007) regarding "Grading Exceptional and Struggling Learners" in more detail will be explained in chart 2.2 wherein this chart will further explain in detail. The phases that require adaptation to the curriculum both curriculum modification (changing curriculum content) and which only requires a change in learning strategies (curriculum accommodation).

$\begin{array}{llr}\text { The picture of Flowchart Intern } & \\ \text { PlanningAccommodating } & \text { Student Diversity (Andini, }\end{array}$
2014)

\section{Materials and Methods}

This type of research used was development research. The development design in this study uses the 4D (four D-Models) design proposed by Thiagarajan, Semmel, \&Semmel (1974) consisting of some phases (1) defining; (2) planning (design); (3) development; and (4) dissemination.

This defining phase will carry out in initial data mining in the form of (1) teacher ability, (2) principals', teachers' and parents' perceptions about diversity, (3) school facilities and infrastructure, and (4) school management. From this preliminary data, a prototype model of curriculum adaptation in inclusive schools was compiled.

The design phase (design) which is a continuation phase of the findings of the data which is then designed a model of curriculum adaptation related to the needs which are found.

From the development phase, it is conducted that the product validation test carried out by curriculum experts, material experts, and media experts as well as user tests, namely teachers. The field trial phase is carried out with a one-shot case study experimental design.

\section{$\times 0$}

Figure 3. One-shot Case Study Experiment Design

Note:

$\mathrm{X}=$ treatment in the form of the use of devices in learning

$\mathrm{O}=$ posttest in the way of assessment results

At the dissemination phase, seminars and workshops on the preparation of curriculum adaptation and learning tools are held.

The define phase is carried out in 25 elementary 
schools implementing inclusive education in 2018 and then continues at the design phase and development of curriculum adaptation models. In 2019, by conducting the dissemination phase, namely by attending seminars and workshops on the implementation of the curriculum adaptation model by sampling 10 elementary schools which implementing inclusive education from 4 districts and one city of Yogyakarta representing from each district 2 elementary schools both public and private. The phase in developing the model can be seen on the figure 4 below.

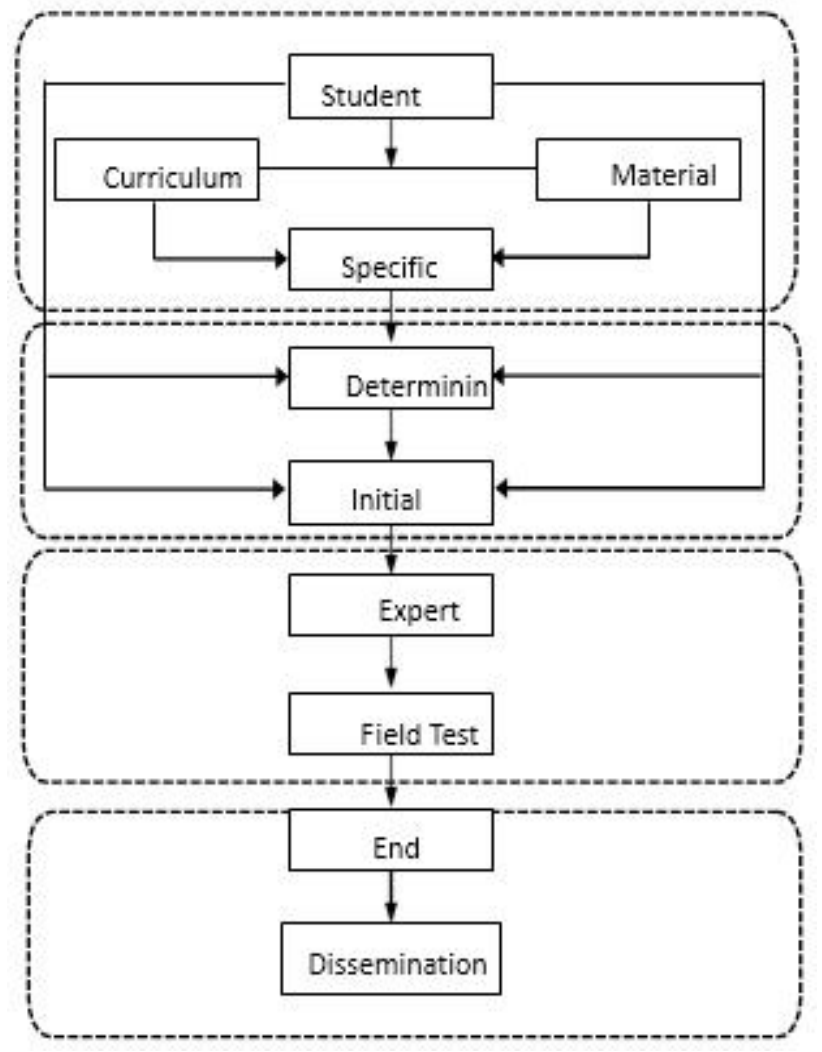

Figure 4. Development Model

At the model development phase, the instruments used in this study were expert and user validation sheets. The assessment is carried out on each aspect of the instrument namely 1) this model is useful to assist teachers in taking steps to know and meet the learning needs of all students in the class, 2) this model is useful to develop teacher skills in meeting the diversity of students in the class, 3 ) this model is useful for building the enthusiasm of teachers in teaching various students in classes, 4) this model is useful in guiding teachers to take the steps in diverse classes learning, 5) this model is useful in helping teachers do the reflection of the learning given.

Valid data analysis of experts and users is done by using averaging assessment scores, which is obtained from experts and users, namely curriculum material experts and inclusive education experts and teachers as users. Data is obtained using questionnaires and qualitative data analysis. The affectivity of the model was assessed by twenty teachers and principals, experts and their mean scores were analyzed to determine the results of the assessments that had been carried out. This analysis is done by calculating the average score given by the observer with the criteria as in Table 1 .

Table 1. Interpretation of the Model usefulness score

\begin{tabular}{|c|c|c|}
\hline No. & Score interval & Criteria \\
\hline 1. & $3,99<\mathrm{X} \leq 5,00$ & Very Effective \\
\hline 2. & $3,49<\mathrm{X} \leq 3,99$ & Effective \\
\hline 3. & $2,99<\mathrm{X} \leq 3,49$ & Effective enough \\
\hline 4. & $1,99<\mathrm{X} \leq 2,99$ & Less Effective \\
\hline 5. & $\mathrm{X} \leq 1,99$ & Very Ineffective \\
\hline
\end{tabular}

\section{Result and Discussion}

In the preparatory phase, a research design has been arranged including research instruments in the form of interview guidelines, questionnaires, classroom observations and test questions for pedagogical competence. In preparing the research design, literature study materials have been obtained, in the form of books and scientific journals related to the research results that will be carried out.

In the next phase, it was determined that the research sites according to the criteria were for obtaining data collection. The research site of the study and the respondents which is determined consisted of principals, teachers, parents or parents representative of students and students in 4 regions and the city of Yogyakarta in Special Region of Yogyakarta province.

At the organizing and carrying out field Activities phase, interviews were carried out at 25 Inclusive Elementary Schools in Special Region of Yogyakarta. From the 25 schools, data collection has been carried out, with an intensive distribution of questionnaires, interviews, observations, and tests with headmasters, teachers, the parent or representative parent and students. From the results of the Study, formed the transcript interviews in purpose to prepare data processing. Data collection is also carried out by observing the learning process in the form of ongoing teaching and learning activities. Besides of taking the documentation in the form of research activities photo, interview activities photo, teaching and learning processes photo have been carried out.

Based on the findings from the obtained data that the perspective of school principals, teachers and parents regarding inclusive education are still in a narrow understanding, where inclusive is still interpreted the same as children with special needs so that there is still labelling that children with special needs are called "inclusive children". This inaccurate perspective of the inclusive true meaning, further the inclusive has an impact on 
acceptance, attitudes and mindset that still discriminates the others so that some teachers assume that children with special needs require special services such as special assistance and assume that inclusive education is the same as education for children with special needs. Preparation is needed to make teachers as agents of change, it means that the teachers will promote the acceptance of diversity in their classrooms and creating a social justice environment (social justice) [13]. Meaning broad inclusive (full inclusion) means the teacher must be able to provide social justice by creating a safe, comfortable environment, accepted to be part of the residents in the surrounding environment. This scheme will affect learning process in the classroom, the teacher will directly consider children with special needs as part of their class so that they will try the various learning methods in purpose all children can learn together and achieve academic achievement. The correct understanding of the meaning of inclusive will be one important factor in the successful implementation of inclusive education [14]. Moreover, behind the narrow perspective of inclusive education, school principals, teachers and parents in Special Region of Yogyakarta elementary school recognize the diversity, that all students in the class are diverse (heterogeneous). The diversity of students in inclusive elementary schools shows the diversity of different ways in learning, but majority of students' learning styles are visual. The interests of each student also vary and the level of student learning readiness in the class also varies, namely self-help, assistance and frustration. Real steps are needed for how to bring up the learning participation of all students in the class. Some literature states that to involve students in the learning process, curriculum and learning must include interaction, exploration, relevance to reality and instruction. The intended instruction is to provide interesting learning adapted from the way students learn [15]. This acceptance of diversity is a positive point in developing friendly learning and it can meet all the student diversity requirement [16].

The attitudes and the acceptance towards the implementation of inclusive education is that both headmasters, teachers and parents received positively with the majority answering agreeing to the implementation of inclusive education. Moreover, the attitude towards the implementation of learning in the classroom is that the teacher gave a statement agreeing to do an assessment to know the abilities of each student, make adjustments to the curriculum, choose various ways of strategy for student to be able to learn, making planning in learning until doing an assessment based on the needs of each student. However, the teacher's pedagogical competence is still low both in the planning, implementation and assessment skills. The lowest point is the ability to compile lesson plans.

Based on the results of the data, it shows that there is support from internal and external schools regarding the implementation of inclusive education that principals, teachers and people have a positive attitude towards inclusive education as evidenced by the questionnaire good attitude on the cultural dimensions, policies and learning practices have a score above $70 \%$. This percentage shows that there is positive acceptance from the implementation of inclusive education in the Special Region of Yogyakarta. Far away from the narrow understanding of the meaning of inclusive education, all components acknowledge that there is a diversity in the classroom.

Pedagogical competencies of Special Region of Yogyakarta teachers still categorized at a low score. This statement proves that teachers need guidance in implementing inclusive education. Regarding the ability to prepare lesson plans is still at $9 \%$. Because of that data, it is required to develop a curriculum adaptation model. The steps in adapting the model of curriculum can be described in figure 5 as follows: 


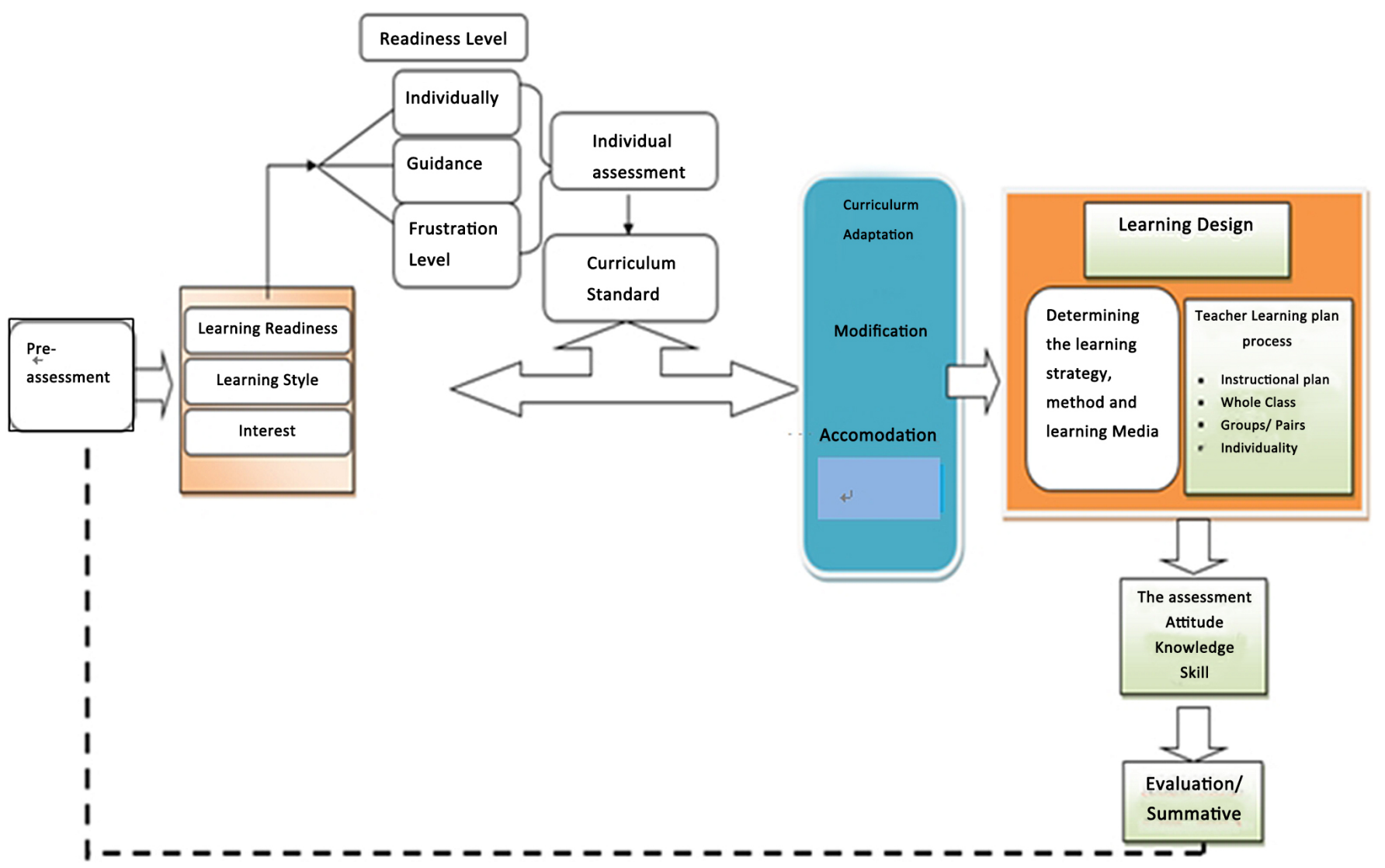

Figure 5. Curriculum Adaptation Model

The step in applying the curriculum adaptation model start from the teacher conducting a pre-assessment with the aim to know the characteristics of each student, especially in learning readiness aspect, learning styles and interests. This step is developed from the basic theory of differentiated instruction where the focus is on students' needs. The curriculum development must consider the students' characteristics in purpose to maximize learning outcomes [17]. Learning readiness by giving a pre-test of the material to be delivered and tracing students' academic abilities through classical assessments that will be known with three levels of ability, namely independence, guidance and frustration, then at the level of independence and frustration will be continued by providing individual assessments to determine the actual level of student ability. The results of the evaluation are then used in deciding curriculum adaptation either modifying or adjusting the standard of achievement or accommodation by finding alternative ways of learning. The development of this curriculum adaptation refers to the grading exceptional learner theory which is known as the student's actual skills will help establish clear standards based on products, processes, and progress criteria, and then report them [18] but there are differences from the application of gradingexceptional learner to this model, that in this developed model, the student who has skills and achievements are very low or above the average class still learning together in the same class setting, while in the model developed by Lee Ann Jung children who need learning modification will study separately from their class. Learning style and learning interest data will be closely related in students' learning motivation and in determining learning models, strategies and methods, and determining learning activities aimed at, so that it is expected that all children with different abilities and characteristics can learn together in the same classroom setting. Therefore, the teacher will design or plan learning experiences based on students' understanding, calculating into account learning activities to the product or learning outcomes that will be made as to the measurement in students' learning successive.

Based on the questionnaire given to record an assessment of the curriculum adaptation model, the majority of teachers said that this model was effective. It is proved by providing advice that in this curriculum adaptation, the assessment also needs to be adjusted. In the learning tools, it is more developed an example of implementation of another learning model, so that it will be an example for teachers in class implementation. Learning will be more effective by making adjustments based on students' skills, involving or collaborating between students in the workgroup and finding alternative ways of learning [19]. The quantitative data from the expert and user validation can be seen in Table 2 .

The dissemination phase was carried out by giving limited seminars and workshops to 10 schools which 
providing inclusive education and they were selected as representatives of 25 elementary schools used in phase 1 . 10 selected primary schools came from 4 regions, and 1 city of Yogyakarta, each representative, consisting of public and private schools also considers the distance either at the central region or suburb. The dissemination phase was widely carried out in all elementary schools throughout Yogyakarta by giving seminars and workshops to the school headmaster and one teacher representative in each school with a total of 190 participants.

Table 2. Validation results of experts and users

\begin{tabular}{|l|c|}
\hline Component & Average Score \\
\hline $\begin{array}{l}\text { Assist the teacher in taking steps } \\
\text { to meet the needs of students }\end{array}$ & 4,6 (Very Effective) \\
\hline $\begin{array}{l}\text { Develop teacher skills when } \\
\text { meeting student diversity }\end{array}$ & 4,6 (Very Effective) \\
\hline $\begin{array}{l}\text { This model is effective to build } \\
\text { the model of teacher morale }\end{array}$ & 4 (Effective) \\
\hline $\begin{array}{l}\text { Helping teachers in the steps of } \\
\text { learning in class }\end{array}$ & 4 (Effective) \\
\hline Helps the teacher to reflect & 4 (Effective) \\
\hline
\end{tabular}

Based on the suggestions from participants at the dissemination stage, it was revealed that the adaptation of this curriculum had been long-awaited by the schools which provid with inclusive education. It is expected that with the adaptation of this curriculum, it will ease for teachers to succeed in providing friendly learning for all children [9]. However, there are certainly many challenges that must be faced in implementing this model. Some teachers also underlined that the need for guidance in implementing this method is needed.

\section{Conclusions}

Today, the teachers are faced with various characteristics of students in the classroom. Government regulations which state that all school institutions must be able to accept all students without exception and prioritizing the closest distance from their place of residence become a strong supporter in the implementation of inclusive education that is accessible to all. However, not all teachers understand in implementing this inclusive education. There are still many teachers who assume that the abilities of all students in the class are equal. Whereas inclusive classes student has different abilities, interests and also different ways of learning. This becomes a challenge to develop their competencies to be better.

An effort is needed in providing non-physical accessibility or a friendly learning environment, one of them is by making curriculum adjustments based on the level of academic readiness, the learning characteristics and the student interest. The results of this study examine the steps in curriculum adaptation namely 1) the pre-assessment in purpose to reveal the learning styles, students' learning modalities, student interests and learning readiness. Self-study readiness is conducted through classical pre-test that will find 3 levels of student ability, namely independent, guidance and frustration (full help), and continued individual test stages at the level of independent and frustrated children by tracing the actual skills, 2) deciding the curriculum adaptation which is divided into modification curriculum (adjusting the achievement / student competence standard and skills) and curriculum accommodation (by finding alternative ways of learning), 3) determine the right learning strategy in designing diverse classroom learning based on learning styles, learning modalities and students' interests. The novelty of this research is the diversity of students' abilities namely, students who have low skill or above the average class can continue in learning with other friends by the same material but different achievements. It is expected that these steps can help teachers in preparing and developing a curriculum which embraces the diversity of students in the classroom and create the learning method that is friendly to all.

\section{Acknowledgments}

This research is fully supported by Affiliation Research Grant from Ministry of Research Technology and Higher Education of Republic of Indonesia with a contract number: PKPT.DIKTI.01/UST/LP3M/K/III/2019.

\section{REFERENCES}

[1] UNESCO, "the Salamanca Statement Framework," Policy, no. June, pp. 7-10, 1994.

[2] T. Booth and M. Ainscow, "Developing learning and participation in schools," 2002.

[3] O. J. F. Andaya1, "Role of teacher in inclusive education," vol. 6, pp. 16-25, 2016.

[4] M. Shevlin, E. Winter, and P. Flynn, "Developing inclusive practice: Teacher perceptions of opportunities and constraints in the republic of Ireland," Int. J. Incl. Educ., vol. 17, no. 10, pp. 1119-1133, 2013.

[5] R. Utaminingsih and A. Rahayu, "Profilpembelajaranipa di sekolahdasartamanmuda se kotayogyakarta," vol. 3, no. 1, pp. 89-97, 2017.

[6] D. W. Andini, "Penerapan Model Differentiated Instruction DalamMengakomodasiKeberagamanSiswadanDampaknya TerhadapInklusifitas, Partisipasi, MotivasiBelajardan Tingkat Pemahaman Siswa Di KelasInklusif," repository.upi.edu, 2014.

[7] P. Tomorrow, "Unleashing the Future: Educators 'Speak Up' about the use of Emerging Technologies for Learning. Speak Up 2009 National Findings. Teachers, Aspiring 
Teachers \& Administrators, May 2010,” 2010.

[8] L. A. Jung, "GRADING Exceptional Learners,” 2010.

[9] U. of W. of S. Louise Barrett, Senior Lecturer et al., "Developing Inclusive Practice in Scotland: The National Framework for Inclusion," no. Inclusion; teacher education; collaboration; diversity, 2015.

[10] N. L. McLeskey, James \& Waldron, Inclusive Schools in Action. Alexandria: ASCD.

[11] T. J. Karten, Inclusion Strategies That Work! Research-Based Methods for the Classroom. California: Corwin Press, 2005.

[12] R. I. Arends, Learning to Teach BelajarUntukMengajar. New York: McGraw Hill Companies, 2007.

[13] N. Pantić and L. Florian, "Developing teachers as agents of inclusion and social justice," Educ. Inq., vol. 6, no. 3, p. $27311,2015$.

[14] F. L. M. Lee, A. S. Yeung, K. Barker, D. Tracey, and J. C. M. Fan, "Teacher Perceptions of Factors for Successful Inclusive Early Childhood Education in Hong Kong," Australas. J. Spec. Educ., vol. 39, no. 2, pp. 97-112, 2015.

[15] L. Taylor and J. Parsons, "Improving Student Engagement," vol. 14, no. 1, 2011.

[16] S. Courey, S. J. Courey, P. Tappe, J. Siker, and P. Lepage, "Teacher Education and Special Education: The Journal of the Teacher Education Division of the Council for Exceptional Children," no. November 2014, 2013.

[17] W. Smets, "High Quality Differentiated Instruction - A Checklist for Teacher Professional Development on Handling Differences in the General Education Classroom," Univers. J. Educ. Res., vol. 5, no. 11, pp. 2074-2080, 2017.

[18] L. A. Jung and T. R. Guskey, "Grading Exceptional Learners Start with High-Quality Reporting," pp. 1-5, 2010.

[19] B. B. College and I. Northern, "Efficacy Beliefs, Background Variables, and Differentiated Instruction of Israeli Prospective Teachers," vol. 96, no. 1, pp. 54-63, 2018. 